\title{
INFOGRAFIS STATIS TEKNIK DASAR RENANG UNTUK ANAK SEKOLAH DASAR
}

\author{
Windi Astuti ${ }^{1}$, Rifda Naifatul Ula ${ }^{2)}$ \\ Program Studi Desain Komunikasi Visual \\ Fakultas Bahasa dan Seni Universitas Indraprasta PGRI \\ J1. Nangka 58 C Tanjung Barat, Jakarta Selatan, 12530, Indonesia \\ windia12apr@gmail.com
}

\begin{abstract}
Abstrak
Banyak anak-anak terutama anak sekolah dasar yang suka bermain air, tetapi jika melihat air di dalam kolam renang ada anak yang takut dan ada pula yang semakin berani untuk menceburkan diri. Dari sinilah diperlukan pengawasan oleh orang dewasa terutama pengajar dan orang tua. Olahraga renang menjadi salah satu upaya pencegahan agar anak terhindar dari bahaya tenggelam. Olahraga renang mempunyai banyak manfaat dan keuntungan untuk membantu pertumbuhan dan perkembangan tubuh, hubungan dengan orang lain, menambah kepercayaan diri sendiri, dan dapat digunakan sebagai kegiatan yang menyenangkan karena rangsangan dingin dapat menyegarkan tubuh. Banyaknya anak sekolah dasar gemar bermain air dan belum mengetahui dasar-dasar renang sehingga rentang memicu terjadinya kecelakaan serta tenggelam di kolam yang dalam. Peran orang dewasa sangat penting agar tidak terjadi hal-hal yang tidak diinginkan dalam aktivitas berenang. Oleh karena itu, dibutuhkan media informasi yang berisi tahapan teknik dasar renang untuk anak sekolah dasar agar dapat membantu para pengajar serta anak-anak dalam belajar cara berenang.
\end{abstract}

Kata Kunci: Infografis Statis, Teknik Dasar Renang, Sekolah Dasar

\begin{abstract}
Many children, especially elementary school children who like to play the water, but if you see the water in the swimming pool there are children who are afraid and some are emboldened to plunge. From where necessary supervision by adults, especially teachers and parents. Swimming sports a solution to prevent children from drowning. Swimming sports has many benefits and advantages to help the growth and development of the body, socialize, interact with others, increase self-confidence, and can be used as a recreational activity due to cold stimulation can refresh your body and feelings. The number of primary school children love to play water and not knowing the basics of pool that ranges trigger accidents and drowning in a deep pool. The role of adults is very important to avoid things that are not desirable in swimming activity. Therefore, it takes the media information that contains the basic engineering stage of swimming for elementary school children in order to help teachers and children in learning how to swim.
\end{abstract}

Keywords: Infographics Static, Basic Techniques Pool, Primary School

Correspondence author: Windi Astuti, windia12apr@gmail.com, Jakarta, and Indonesia

c) (i) 8

This work is licensed under a $C C-B Y-N C$ 


\section{PENDAHULUAN}

Anak-anak, khususnya anak usia sekolah dasar, pada dasarnya senang bermain dan belajar, termasuk bermain dengan air. Mereka sudah terbiasa mandi berlama-lama sambil bermain air hujan, bahkan bermain air di sungai, selokan, serta memainkan keran air. Namun, apa bila anak-anak disuruh bermain-main air, tetapi air itu adalah air di kolam renang, maka kadangkadang keberanian anak-anak menjadi surut. Hal-hal semacam inilah yang merupakan tantangan bagi para guru pendidikan jasmani dan pelatih renang, bagaimana membuat anak-anak tetap dapat menikmati air di kolam renang?

Cabang olahraga yang dapat menunjang tercapainya tujuan tersebut, salah satunya adalah cabang olahraga renang. Alasan mengapa cabang renang dapat digunakan untuk mencapai tujuan pendidikan jasmani adalah karena renang memiliki banyak manfaat. Manfaat tersebut di antaranya dapat membantu pertumbuhan dan perkembangan tubuh, bersosialisasi dan berinteraksi dengan orang lain, menambah kepercayaan pada diri sendiri, dan dapat digunakan sebagai kegiatan rekreatif karena rangsangan dingin dapat menyegarkan tubuh dan perasaan. Belajar renang juga dapat menambah pengetahuan siswa tentang gerak yang efektif dan efisien, sifat-sifat air, teori renang dan lain-lain.

Renang merupakan suatu aktivitas yang dilakukan di air. Dengan demikian, air merupakan sarana utama terlaksananya kegiatan ini. Melakukan aktivitas di air sangat berbeda dengan aktivitas di darat. Untuk itu dalam pembelajaran renang kepada anak-anak, terlebih dahulu harus diperkenalkan karakteristik air sehingga mereka dapat beradaptasi dengan sifat-sifat air. Beberapa kendala yang sering dihadapi dalam pembelajaran renang kepada anak-anak, yaitu: mempertahankan posisi mengapung dengan benar, meluncur dengan posisi yang benar (stream line), melakukan pernapasan di air, dan secara keseluruhan adalah bagaimana menguasai teknik gaya tertentu dengan efisien dan efektif.

Banyaknya anak sekolah dasar gemar bermain air dan belum mengetahui dasar-dasar renang sehingga rentang memicu terjadinya kecelakaan serta tenggelam di kolam yang dalam. Sikap anak-anak yang selalu ingin tau serta aktif mendorong dan mencipratkan air ke muka anak lainnya tersebut melakukan hal-hal yang berbahaya, seperti mendorong temannya, bercanda di air, maupun terjatuh ataupun terpeleset. Peran orang dewasa sangat penting agar tidak terjadi halhal yang tidak diinginkan dalam aktivitas berenang. Untuk itu perlu adanya penyampaian sarana pesan berupa media informasi agar dapat diberitahukan kepada khalayak tentang teknik dasar berenang untuk anak $\mathrm{SD}$, media infografis statis dirasa tepat sasaran oleh penulis.

\section{METODE PENELITIAN}

Metode penelitian yang digunakan dalam penelitian ini adalah jenis penelitian kualitatif yaitu turun ke lapangan untuk wawancara dengan narasumber langsung bagaimana teknik dasar renang pada anak sekolah dasar. Dengan metode kualitatif ini bisa mendapatkan informasi langsung tentang berbagai macam teknik renang dan data yang dibutuhkan.

Untuk memperoleh data, peneliti menggunakan beberapa metode yang disesuaikan pada jenis penelitian kualitatif dengan cara, antara lain:

1. Studi Pustaka

Dari data yang didapat, peneliti menggunakan jenis penelitian kualitatif yaitu studi kepustakaan metode pengumpulan data yang menggunakan referensi buku, jurnal, dan website yang berkaitan pada materi yang mendukung penelitian ini

2. Wawancara

Wawancara dilakukan dengan bapak Denny Anggeri, selaku pelatih renang dan ketua perkumpulan renang Meteor Lintas Aquatic di tempat beliau bekerja, di Kolam Renang GOR Ciracas yang beralamat di Jl Raya Bogor km 25-26 Cijantung, Pasar Rebo Jakarta Timur pada 26 Mei 2019. Mengenai berbagai teknik dasar renang untuk anak sekolah dasar.

\section{HASIL DAN PEMBAHASAN}

Ada banyak hal yang harus dipahami dalam pembelajaran renang bagi anak-anak sekolah dasar yang berurusan dengan pemenuhan kebutuhan anak-anak peran orang tua juga yang 
mengharapkan anak-anak menjadi berenang dengan baik. Oleh karena itu, perlu perhatian yang tepat bagaimana pembelajaran renang untuk anak-anak dapat dilakukan dengan baik dan harapan tersebut dapat dicapai, meskipun ada hambatan dalam proses pembelajaran berenang. Mulai dari siswa di sekolah dasar yang memiliki karakteristik khusus, belajar untuk mengetahui bahwa kegiatan di air memerlukan adaptasi yang harus dipersiapkan dengan seksama. Olahraga renang memiliki teknik khusus. Oleh karena itu, anak-anak perlu dipersiapkan secara fisik atau psikologis. Ketika anak-anak belajar bagaimana cara berenang, mereka harus dikenalkan dengan air, belajar teknik dasar pernafasan. Artikel ini akan memaparkan hal-hal penting yang harus diperhatikan dalam belajar teknik untuk anak-anak di sekolah dasar untuk mengatasi hambatan yang akan dihadapinya saat berenang, sehingga harapan dari peserta didik dapat tercapai.

\section{Karakteristik Anak}

Pada masa anak-anak (usia 6-12 tahun) pertumbuhan cenderung stabil. Pada masa anakanak banyak mengalami perubahan-perubahan di dalam tubuh yang meliputi meningkatnya tinggi dan berat badan.

Anak-anak SD mempunyai karakteristik berdasarkan tingkat kelas maupun jenis kelamin, walaupun sudah tentu ada faktor-faktor lain yang sangat spesifik untuk tidak dikesampingkan. Seorang pakar pendidikan jasmani, menurut (Sukintaka, 1983) Anak-anak SD, umurnnya berumur antara 6-13 tahun. Kelompok umur pendidikan pertama usia antara 6-8 tahun, kelompok umur pendidikan kedua antara 6-12 tahun, dan kelompok umur pendidikan ketiga antara 12-13 tahun. Kelompok-kelompok murid di Indonesia diperkirakan bahwa untuk kelompok umur pertama, anak duduk di kelas 1 dan 2, untuk kelompok umur kedua duduk di kelas 3 dan 4, sedangkan kelompok umur ketiga anak duduk di kelas 5 dan 6. Tiap-tiap kelompok umur pendidikan itu mempunyai sifat masing-masing sesuai dengan pertumbuhan dan perkembangannya.

Masih menurut sumber yang sama, dinyatakan bahwa masing-masing kelompok umur pendidikan tersebut dapat dibedakan lagi berdasarkan aspek fisik, psikologis, keinginan bermain dan bersosialisasi. Ada hal yang sangat perlu untuk ditekankan, yaitu anak-anak supaya diberi kebebasan untuk bergerak bebas, agar dalam dirinya timbul kreativitas.

Berdasarkan rasa ego, anak-anak kelas bawah, egonya sangat tinggi. Contoh yang paling menonjol adalah, apabila mereka sedang menikmati permainannya, maka dia tidak mau diganggu, sedangkan pada anak-anak kelas atas, sudah cukup nampak keinginannya untuk bersosialisasi. Hal ini ditandai dengan mereka mulai lebih menikmati bermain bersama dengan teman-teman sebayanya, dalam suatu permainan beregu kelompok. Guru tentunya sangat berkepentingnan memperhatikan perbedaan-perbedaan ini, yang akan sangat bermanfaat untuk menentukan langkah-langkah pembelajaran yang tepat.

\section{Pengenalan Air}

Langkah awal untuk pembelajaran renang kepada anak-anak SD adalah memberikan pengenalan air, hal ini mengingat karena air memiliki karakteristik tertentu yang harus dipahami oleh para siswa. Menurut (Soekarno, 1979) siswa harus dikenalkan dengan sifat-sifat air, seperti apabila terkena air akan basah, berada di air terasa dingin, serta adanya hambatan apabila bergerak di air. Menurut pendapat (Milke, 1988), semua anak termasuk anak yang sudah berpengalaman perlu memahami bagaimana mempelajari sifat-sifat khas air, sehingga akan memiliki perasaan aman dan percaya diri untuk dapat bergerak di air. Pengenalan terhadap air pada prinsipnya bertujuan agar kegiatan tersebut nantinya berguna pada waktu anak-anak belajar gaya renang yang sebenarnya. (Sukintaka, 1983) berpendapat, bahwa secara psikologis ada beberapa unsur yang harus dikembangkan pada diri anak-anak, yaitu rasa senang, keberanian, percaya diri, serta keuletan. Apabila unsur-unsur tersebut dapat dikembangkan dengan baik, maka pembelajaran renang akan dapat berlangsung dengan baik pula. Penyampaian materi pengenalan air harus direncanakan dengan sebaik-baiknya, diawali dengan kegiatan yang sangat mudah, dan secara bertahap menuju ke tingkat yang semakin sulit. Perencanaan program pengenalan air, harus disesuaikan dengan kondisi anak-anak, jumlah anak, tempat yang digunakan, serta pemilihan 
macam aktivitas yang diberikan. Langkah pertama dan utama untuk dilakukan adalah menciptakan rasa aman pada diri anak-anak, langkah berikutnya berusaha membuat suasana yang menyenangkan.

\section{Gerak Dasar Renang}

Sebelum belajar renang lebih baik bila mengenal gaya dalam renang yang pada umumnya digunakan diantaranya adalah Gaya Bebas, Gaya Kupu-kupu, Gaya Punggung, Gaya Dada. Keempat gaya ini merupakan gaya dari renang yang dipertandingkan dalam kejuaraan renang. Apabila telah mengenal tentang gaya dalam renang, maka selanjutnya adalah mulai dengan bagaimana mengenal air dan apa yang dilakukan apabila ingin belajar renang. Dari gaya renang yang harus dipelajari baiknya terlebih dahulu mengenal bagaimana sebaiknya mempelajari dasardasar renang. Kenalilah olahraga renang ini dengan bagaimana agar dapat menyesuaikan diri dengan suhu air. Paling ideal untuk mereka yang belajar dikolam adalah pada kedalaman $0,75-1$ meter, dimana kedalaman ini dapat memungkinkan bagi mereka yang mempelajari renang dapat berdiri serta memudahkan bagi mereka yang akan mempelajari renang dapat berdiri serta memudahkan dirinya untuk mengendalikan keseimbangan tubuhnya terhadap air.

Menurut Denny Anggeri dalam wawancara (2019), gerak dasar renang ada beberapa hal yang perlu diketahui di antaranya adalah:

a. Pertama belajar dengan melatih pernafasan, tekniknya yaitu tarik nafas panjang melalui mulut lalu tahan.

b. Kedua masukan wajah ke dalam air, tahan nafas sebisa mungkin lalu ambilah nafas secara perlahan-lahan dengan menggunakan hidung dan mulut secara bersamaan. Dalam hal ini anak diajarkan pernafasan supaya dapat beradaptasi di dalam air.

c. Setelah menguasai dengan baik mengatur pernafasan yang baik, selanjutnya mencoba gerakan meluncur dari dinding kolam, dimulai dengan berdiri pada dasar kolam kemudian salah satu telapak kaki menempel pada dinding kolam untuk siap menolak, dengan sikap kedua belah tangan berkaitan pada kedua jarinya dimana lengan lurus mengarah ke atas dan sebagai patokan kedua lengan lurus dengan menyentuh telinga kedua jari berkaitan lurus berada di atas kepala. Bungkukkanlah tubuh, sehingga kedua ujung tangan dapat menyentuh permukaan air, selanjutnya doronglah bagian telapak kaki yang semula ditempelkan pada dinding secara perlahan-lahan untuk melakukan luncuran, pada saat sebelum melakukan luncuran ambilah udara sebanyak-banyaknya melalui mulut lalu buanglah sisa udara di bawah permukaan air pada saat melakukan luncuran secara bertahap serentak menolakkan telapak kaki dari di dinding kolam.

d. Setelah terbiasa melakukan luncuran, selanjutnya ialah latihan kaki. Meluncur dengan menggerakan kaki keatas dan ke bawah dengan ritme yang teratur. Latihan kaki ini dilakukan secara berulang ulang untuk dapat membuat gerakan kaki yang stabil.

e. Jika meluncur dengan kaki yang digerakan sudah terbiasa, maka selanjutnya menggunakan papan luncur sebagai pegangan agar tubuh tetap seimbang dan mengapung dengan sempurna. Meluncur dengan papan harus dengan kondisi yang rileks dan tidak tegang karena sikap yang tegang memungkinkan sulit mengendalikan posisi tubuh yang berakibat tubuh turun kebawah.

f. Dengan memegang papan dengan salah satu tangan, tangga satunya mulai latihan gerakan teknik tangan gaya bebas. Belajar teknik tangan ini dapat dilakukan secara berulang-ulang sehingga biasa merasakan keseimbangan sikap inilah nantinya digunakan pada saat berenang.

\section{Gaya Renang}

Gaya renang dapat diajarkan kepada para siswa setelah mereka telah menguasai dasardasar renang dengan cukup baik. Ada beberapa gaya renang, yaitu gaya atau bebas, gaya dada, gaya punggung, dan gaya kupu-kupu. Gaya renang yang biasa diajarkan lebih dahulu adalah gaya bebas dan gaya dada. Gaya bebas lebih sering diajarkan daripada gaya yang lain, karena gaya bebas lebih berfungsi sebagai daya tahan. 
Selain gaya bebas, gaya yang sering diajarkan lebih dahulu pada anak yang baru belajar renag adalah gaya dada yang disebut juga dengan breaststroke. Menurut (Heller, 1986) gaya dada adalah gaya yang pertama dipelajari oleh banyak orang. Matthew Webb dalam (M. Murni, 2000), pada tahun 1875 menjadi orang pertama yang menyeberangi selat Channell di Inggris dengan gaya dada. Pada masa dulu, abad 19, gaya dada banyak diajarkan di sekolah-sekolah, sehingga gaya ini sering disebut sebagai school slag. Kedua gaya ini sering kali diajarkan pertama bagi yang baru mulai belajar renang, sehingga gaya ini disebut juga sebagai renang dasar. Setelah menguasai renang gaya dasar dengan baik, barulah kemudian belajar gaya yang lain, yaitu gaya punggung atau kupu-kupu. Unsur teknik dari berbagai gaya renang, pada dasarnya sama, yaitu posisi badan, gerakan kaki, dan gerakan pemapasan. Perbedaan dan masing-masing gaya terletak pada teknik gerakannya. Mengingat materi gerakan dalam gaya renang sangat kompleks, maka dalam pembelajaran perlu diperhatikan penggunaan metode belajar yang tepat sangat diperlukan.

\section{Konsep Dasar Perancangan Infografis Teknik Dasar Renang Untuk Anak SD}

\section{Analisis Khalayak}

Konsep dasar perancangan dari infografis teknik dasar renang untuk anak SD ini sebagai informasi bagi khalayak yang dituju dari perancangan infografis ini. Berikut adalah penjelasan mengenai analisis khalayak yang dituju dari segi geografis, demografis, targetting serta positioning. Segmentasi secara geografis, masyarakat yang cocok menjadi target adalah daerah perkotaan karena minat mempelajari renang lebih tinggi diperkotaan daripada di desa, namun tidak memungkinkan daerah di pedesaan dapat menjadi khalayak yang dituju.

Segementasi secara demografis masyarakat yang cocok menjadi target adalah semua jenis kelamin, terutama ibu muda dan tenaga pengajar usia 21 hingga 30. Status sosial berada pada tingkat ekonomi menengah hingga mengengah ke atas, karena bagi kalangan menengah dan menengah ke atas, aktivitas yang menunjang prestasi seperti renang ini sangat dibutuhkan bagi anak mereka. Segmentasi secara psikografis, masyarakat yang cocok menjadi target adalah masyarakat yang memiliki ketertarikan dengan dunia olahraga khususnya renang serta para praktisi pengajar yang ingin memberikan ekskul atau kegiatan diluar sekolah. Anak sekolah usia SD yang tertarik dengan olahraga pun dapat menjadi target infografis yang dituju.

\section{Konsep Visual}

a. Gaya Visual

Gaya visual yang dipilih dalam infografis statis ini menggunakan gaya flat design, karena gaya ini sederhana dan mudah dipahami oleh khalayak. Gaya visual flat design juga populer dan digunakan oleh para kreator dalam membuat karya desain. Menggunakan warna cerah tanpa gradasi dinilai lebih sederhana dalam gaya visual flat design.
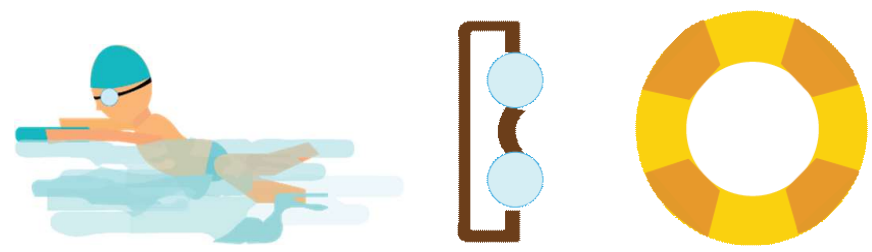

Gambar 1. Gaya Visual

Sumber: Rifda, 2019

b. Ikon

Ikon yang digunakan dalam perancangan infografis ini menggunakan gaya flat design dengan mencerminkan suatu benda dengan sederhana tanpa menghilangkan bagian yang menjadi ciri khas dan karakteristiknya. 
c. Skema dan Dasar Pemilihan Warna

Warna adalah faktor terpenting dalam komunikasi visual karena warna memberikan kesan psikologis, sugesti dan juga suasana bagi yang melihatnya (Soewignjo, 2013). Oleh sebab itu, pemilihan warna harus dipertimbangkan dan memperhatikan siapa audiensnya, kesan psikologis apa yang ada pada warna tertentu dan suasana seperti apa yang ingin diciptakan.

Tema warna yang digunakan adalah warna selaras harmonis dengan warna turunannya dan warna pendukungnya yaitu warna biru dan coklat sebagai penegas dan penyeimbang, kombinasi warna turunan cocok diterapkan pada media infografis dinamis karena menurut teori susunan warna (Anggraini, S., \& Nathalia, 2014) kombinasi warna harmonis terlihat lembut karena perpaduan warna satu dengan warna lain dengan perubahan halus, tema warna turunan dapat membuat audiens tidak bosan untuk berlama-lama melihat infografis. Secara keseluruhan konsep mengunakan warna hangat dan dapat membuat target khalayak tidak merasa bosan berlama-lama melihat infografis.

Warna yang digunakan dalam infografis ini di antaranya biru, cokelat dan oranye. Warna biru memiliki kesan air atau laut, ini identik dengan penggambaran teknik dasar renang untuk anak SD yang biasanya anak-anak berenang didalam kolam renang. Selain itu, menurut psikologi warna biru memiliki efek menenangkan pikiran, dan meningkatkan konsentrasi, sehingga warna biru dapat digunakan untuk memfokuskan khalayak untuk membaca infografis statis ini. Warna cokelat merupakan warna netral yang natural, warna coklat dipilih pada infografis ini karena pada umumnya warna tubuh manusia berwarna cokelat. Dalam psikologis warna cokelat berupa kenyamanan, kehangatan. Warna oranye memberi kesan hangat dan bersemangat serta memberikan kesan petualangan, pada pemilihan huruf warna oranye juga sebagai penegasan text didalam media ini.

d. Pemilihan Huruf

Anggraini dan Nathalia (2014: 58-63) menjelaskan tentang klasifikasi huruf yaitu Serif terdiri dari Old style, Transitional, Modern dan Egyptian (Slab Serif). Slab Serif memiliki kaki yang lebih tebal. Selain Serif juga ada kategori Sans Serif yang diartikan tanpa sirip tau tanpa serif, jadi huruf jenis ini tidak memiliki sirip pada ujung hurufnya dan memiliki ketebalan huruf yang sama. Sans Serif melambangkan kesederhanaan, lugas berkesan masa kini. Huruf jenis ini cocok berdampingan dengan grafis yang terlihat modern. Huruf yang dipilih menggunakan jenis font Baloo Reguler, merupakan jenis huruf sans serif atau tidak berkait. Huruf ini lebih mengesankan karakter hangat dan bersahabat, dan juga memiliki tingkat keterbacaan yang baik.

\section{Hasil Perancangan Infografis Statis Teknik Dasar Renang Untuk Anak SD}

Perencanaan penempatan media statis ini ialah pada tempat anak bermain dikolam renang sehingga mampu mencapai target audiens yang dituju, peran orang tua pun penting dalam pembelajaran teknik dasar renang untuk anak SD sehingga anak menjadi paham akan teknik dasar renang. Selain itu, media ini nantinya juga akan ditempatkan di media sosial seperti Instagram, Facebook, Twitter, maupun media sosial lain. 


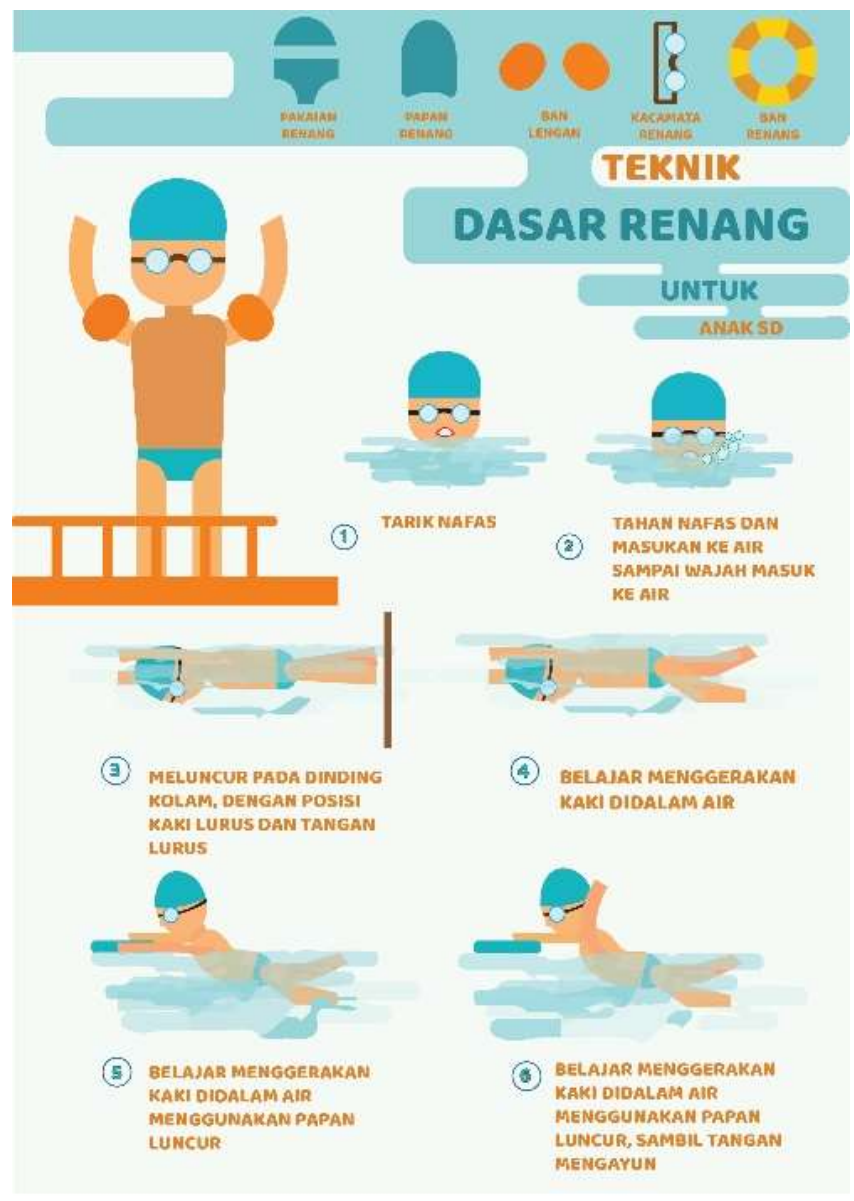

Gambar 2. Infografis Statis Sumber: Rifda, 2018

\section{SIMPULAN}

Banyak anak anak yang jika melihat kolam renang langsung berlari lalu menceburkan diri dan bermain dengan air. Hal itu tidak mereka sadari dapat menimbulkan bahaya tenggelam. Anak anak sekolah dasar memiliki karakteristik yang berbeda beda, dari emosional, psikologis, dan fisiknya. Oleh karena itu di perlukan pengawasan orang dewasa agar terhindar dari hal hal yang tidak diinginkan. Cara lain yaitu dengan mengajarkan anak bagaimana cara berenang yang baik dan benar. Ada beberapa tahapan-tahapan teknik yang perlu diajarkan kepada anak sekolah dasar dalam berenang. Salah satunya membiarkan anak beradaptasi dengan air kolam renang, belajar pernafasan dan melakukan gerakan meluncur serta teknik gerakan tangan dan kaki yang benar. Gaya visual, warna dan huruf dipilih guna memberikan kesan yang jelas dan padat bagi pesan yang ada pada infografis, tetapi dikombinasikan dan dikomposisikan agar menarik perhatian. Sebagai media yang informatif, infografis statis ini dibuat dengan tampilan sederhana dan mudah dimengerti agar pesan tersampaikan ke khalayak.

\section{DAFTAR PUSTAKA}

Anggraini, S., \& Nathalia, K. (2014). Desain komunikasi visual: Dasar-dasar panduan untuk pemula. Bandung: Nuansa Cendekia.

Arifin, B. (2018). Pengembangan pengenalan air dengan teknik gaya bebas untuk sekolah dasar. Jurnal Pemikiran Dan Pengembangan SD, 6(2), 173. 
Heller, D. (1986). Belajar berenang. Bandung: CV Pioner Jaya.

M. Murni. (2000). Renang. Jakarta: Departemen Pendidikan dan Kebudayaan.

Milke, W. (1988). Renang (teknik, sarana dan fasilitas). Semarang: DaharaPrize.

Soekarno. (1979). Renang dan metodik. Jakarta: PT Karya Uni Press.

Soewignjo, S. (2013). Seni mengatur komposisi warna digital. Yogyakata: Taka Publisher.

Sukintaka. (1983). Renang dan Metodik bagi Guru. Jakarta: PT Rosda Jaya. 